Check for updates

Cite this: RSC Adv., 2019, 9, 11142

Received 14th January 2019

Accepted 21st March 2019

DOI: $10.1039 / c 9 r a 00315 k$

rsc.li/rsc-advances

\title{
Synthesis of novel 10,11-methylenedioxy- camptothecin glycoside derivatives and investigation of their anti-tumor effects in vivo
}

\author{
Guanzhao Wu, $\neq^{\mathrm{ab}}$ Xiaoyuan Mai,,$^{\mathrm{ab}}$ Feng Liu, $\neq^{\mathrm{ac}}$ Mingming Lin, ${ }^{\mathrm{c}}$ Xueyang Dong, ${ }^{\text {ab }}$
} Qingliang $\mathrm{Xu}{ }^{a}{ }^{\mathrm{a}}$ Cui Hao, ${ }^{d}$ Lijuan Zhang, ${ }^{d}$ Rilei $\mathrm{Yu}^{\star a b}$ and Tao Jiang (D) *ab

\begin{abstract}
10,11-Methylenedioxy-camptothecin (FL118) is a novel camptothecin analogue that possesses exceptional antitumor efficacy in human tumor xenograft models. The aim of the current study was to develop novel 20-substituted FL118 derivatives coupled with glycosyl-succinic acid esters with improved antitumor efficacy. These FL118 glycoside derivatives were designed, synthesized and their cytotoxicity evaluated in three tumor cell lines (A-549, MDA-MB-231 and RM-1). All of the derivatives showed superior in vitro cytotoxic activity and were more potent than irinotecan in A549 and MDA-MB-231 cells. In mouse prostate cancer cells RM-1, 10,11-methylenedioxy-camptothecin rhamnoside $11 \mathrm{~b}$ displayed significant activities with $\mathrm{IC}_{50}$ of $48.27 \mathrm{nM}$. Western blot analysis demonstrated that $11 \mathrm{~b}$ inhibited survivin expression and induced cancer cells apoptosis. Further cell cycle analyses clearly showed 11b induced G2/M phase cell cycle arrest. Molecule docking studies suggested that the binding mode of $11 \mathrm{~b}$ was different from that of the crystal complex of ligand topotecan in Top1/DNA. Importantly, 11b showed high in vivo antitumor efficacy in the RM-1 mouse model with transplantation of prostate cancer $(\mathrm{TGl}=44.9 \%)$ at dose of $9 \mathrm{mg} \mathrm{kg}^{-1}$ without apparent toxicity.
\end{abstract}

\section{Introduction}

$20(S)$-Camptothecin (CPT) is a cytotoxic quinoline alkaloid (Fig. 1) that was discovered by Wall et al. in $1966 .{ }^{1}$ Over the past five decades, many CPT derivatives were synthesized and tested, but most of the compounds designed so far are highly toxic to normal tissues or have other shortcomings making them unsuitable candidates for cancer treatment. To date, only two camptothecin analogues (i.e. irinotecan and topotecan, Fig. 1) have been commercially approved by the FDA for treatment of cancer in clinic. ${ }^{2,3}$ However, resistance to irinotecan and topotecan is often observed in practice, especially in patients using these drugs for an extended period of time. ${ }^{4-9}$

The anticancer agent 10,11-methylenedioxy-camptothecin (FL118), a CPT analogue with a methylenedioxy group linked

${ }^{a}$ Key Laboratory of Marine Drugs, Chinese Ministry of Education, School of Medicine and Pharmacy, Ocean University of China, 5 Yushan Road, Qingdao 266003, China. E-mail: jiangtao@ouc.edu.cn; ryu@ouc.edu.cn; Tel: +86-532-820-32712

${ }^{b}$ Laboratory for Marine Drugs and Bioproducts of Qingdao National Laboratory for Marine Science and Technology, Qingdao 266003, China

'Department of Medical Imaging, Wei Fang Medical University, 7166 Baotongxi Street, Weifang 261000, China

${ }^{d}$ Institute of Cerebrovascular Diseases, Affiliated Hospital of Qingdao University, Qingdao, 266003, China

$\dagger$ Electronic supplementary information (ESI) available. See DOI: 10.1039/c9ra00315k

\$ These authors contributed equally. to positions 10 and 11 of the A-ring (Fig. 1), was recently identified through small molecule inhibitor screening and shows much higher anticancer activities in several different cancer types both in vitro and in vivo. ${ }^{10}$ It has been previously demonstrated that although FL118 is not a better Top1 inhibitor than the clinically used camptothecin analogues, ${ }^{10}$ FL118 is able to selectively inhibit multiple cancer survival and proliferation-
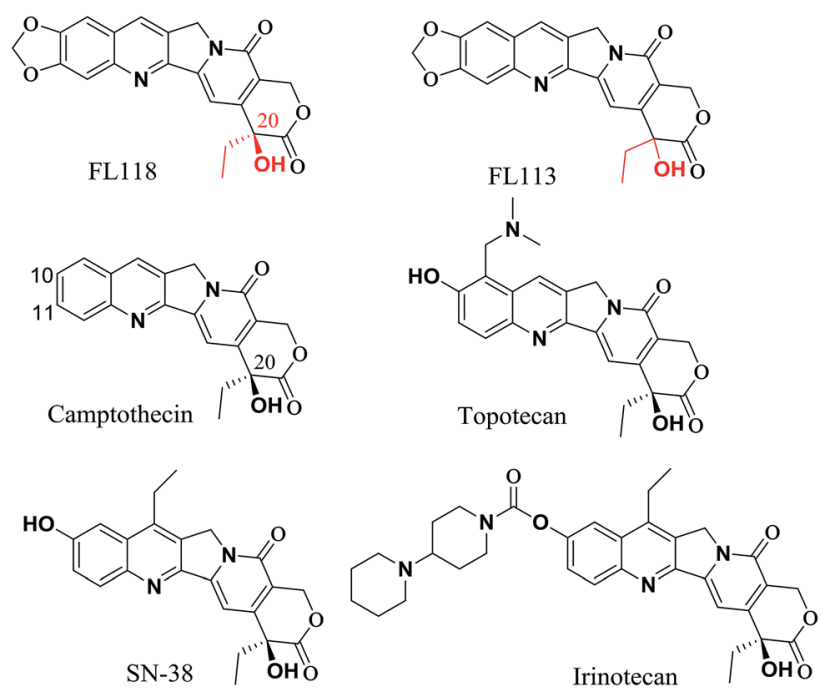

Fig. 1 Comparison chemical structure of FL118 with FL113, camptothecin, irinotecan, SN-38 (active metabolite of irinotecan) and topotecan. 
associated antiapoptotic proteins (survivin, ${ }^{11-21} \mathrm{XIAP},{ }^{22-26}$ and cIAP2 (ref. 27 and 28)) and the Bcl-2 family (Mcl-1 (ref. 29-35)), which contribute to FL118 function and antitumor activity. ${ }^{11,36}$

The superior antitumor efficacy of FL118 has inspired our interest in the development of antitumor drugs using the core structure of FL118 as a promising scaffold for the generation of novel FL118 analogs. Results from previous studies suggest that modification of the free hydroxyl group at 20-position in camptothecin via ester bonds could be a promising way to improve in vivo antitumor efficacy and reduce gastrointestinal toxicity. ${ }^{37-40}$ The idea of replacing the hydrogen atom in the hydroxyl group of FL118 with saccharide is to improve its water solubility and further decrease its normal tissue toxicity without affecting its antitumor activity.

In the present study, different configurations of 10,11methylenedioxy-camptothecin glycosyl substituted analogs were synthesized and their antitumor activity was evaluated. The two fragments, including saccharide moiety and succinic acid ester, were incorporated into the structure at the 20-position of 10,11-methylenedioxy-camptothecin to improve its water solubility.

\section{Results and discussion}

\subsection{Chemistry}

According to published procedures, ${ }^{41,42}$ the glycosyl donors 2,3,4,6-tetra-O-acetyl-D-glucopyranose $3 \mathbf{3 a}$ or 2,3,4-tri-O-acetyl-Lrhamnose $\mathbf{3 b}$ was prepared from D-glucose $\mathbf{1 a}$ or L-rhamnose $\mathbf{1 b}$ in $68 \%$ or $63 \%$ yield, respectively. The obtained compound $3 a$ or $3 \mathbf{b}$ was then reacted with succinic anhydride to form $\beta-O-$ $(2,3,4,6$-tetra- $O$-acetyl- $\beta$-D-glucosyl)-succinic acid monoester $4 \mathbf{a}$ by the yield of $89 \%$ or $\alpha$-O-(2,3,4-tri- $O$-acetyl- $\alpha$-L-rhamnosyl)succinic acid monoester $\mathbf{4 b}$ by the yield of $87 \%$ (Scheme S1 $\dagger$ ).

The synthetic routes to form target compounds (9a-11a, $\mathbf{9 b}$, 11b) are outlined in Scheme 1. 2-Amino-4,5methylenedioxybenzaldehyde 5 was prepared according to the published procedures. ${ }^{43,44}$ Different configurations of compounds 20(R)-10,11-methylenedioxy-camptothecin $\quad \mathbf{9}$, 20(RS)-10,11-methylenedioxy-camptothecin 10 and 20(S)-10,11methylenedioxy-camptothecin $\mathbf{1 1}$ was accomplished using Friedlander condensation with $80-85 \%$ yield between 6-amino piperonal 5 and the known tricyclic keto lactone $\mathbf{6 , 7}$ or $\mathbf{8}$, respectively (Scheme S2 $\dagger$ ). ${ }^{45,46}$ Coupling of compound 9 with glycosyl donors $\mathbf{4 a}$ or $\mathbf{4 b}$, catalyzed by EDCI and DMAP, resulted in pure $\mathrm{R}$ steric configuration 10,11-methylenedioxycamptothecin glucoside $9 \mathbf{a}\left([\alpha]_{\mathrm{D}}^{14}=284.25^{\circ}\right)$ or rhamnoside $\mathbf{9 b}$ $\left([\alpha]_{\mathrm{D}}^{14}=98.75^{\circ}\right)$ in $68 \%$ and $71 \%$ yield, respectively. Similarly, coupling of compound $\mathbf{1 0}$ with glycosyl donor $\mathbf{4 a}$, resulted in racemic RS configuration 10,11-methylenedioxy-camptothecin glucoside 10a $\left([\alpha]_{\mathrm{D}}^{14}=32.75^{\circ}\right)$ with a $63 \%$ yield. The pure $\mathrm{S}$ steric configuration 10,11-methylenedioxy-camptothecin glycoside 11a $\left([\alpha]_{\mathrm{D}}^{14}=-27.75^{\circ}\right)$ and 11b $\left([\alpha]_{\mathrm{D}}^{14}=-166.50^{\circ}\right)$ were obtained by coupling of compound $\mathbf{1 1}$ with glycosyl donors $\mathbf{4 a}$ and 4b in $61 \%$ and $73 \%$ yield, respectively (Scheme 1).

\subsection{Cytotoxicity and $\mathrm{IC}_{50}$}

The in vitro cytotoxicity of the newly synthesized compounds were determined in three tumor cell lines, A-549 (human lung carcinoma), MDA-MB-231 (human breast carcinoma) and RM-1 (mouse prostate carcinoma) while irinotecan and FL118 were used as positive controls. To obtain $\mathrm{IC}_{50}$ values for each compound, all three cancer cell lines were treated with series of concentrations of each compound. As shown in Table 1, all target compounds exhibited significant cytotoxic activities against the three tumor cell lines in vitro with $\mathrm{IC}_{50}$ values ranging from $2.32 \mathrm{nM}$ to $4.53 \mu \mathrm{M}$. All of the new designed compounds were less potent than FL118, the core structure of these synthesized compounds, against A549 and MDA-MB-231 cell lines. In comparison, all the new compounds exhibited superior cytotoxicity to irinotecan in the two human cell lines. In addition, all of the compounds were more potent against A549 cells, moreover, 10,11-methylenedioxy-camptothecin rhamnoside 11b (the S-type enantiomer) showed the most significant cytotoxic effect with $\mathrm{IC}_{50}$ of $83 \mathrm{nM}$. The $\mathrm{IC}_{50}$ values in Table 1 indicated that the A-549 cell line was more sensitive to these compounds than the MDA-MB-231 cell lines.

For both human cancer cell lines, the compounds coupled with rhamnose (9b and $\mathbf{1 1 b}$ ) were generally more potent than those coupled with glucose (9a and 11a), indicating that the rhamnose may be a better group in developing new antitumor agents. Furthermore, the configuration of the 20-position is

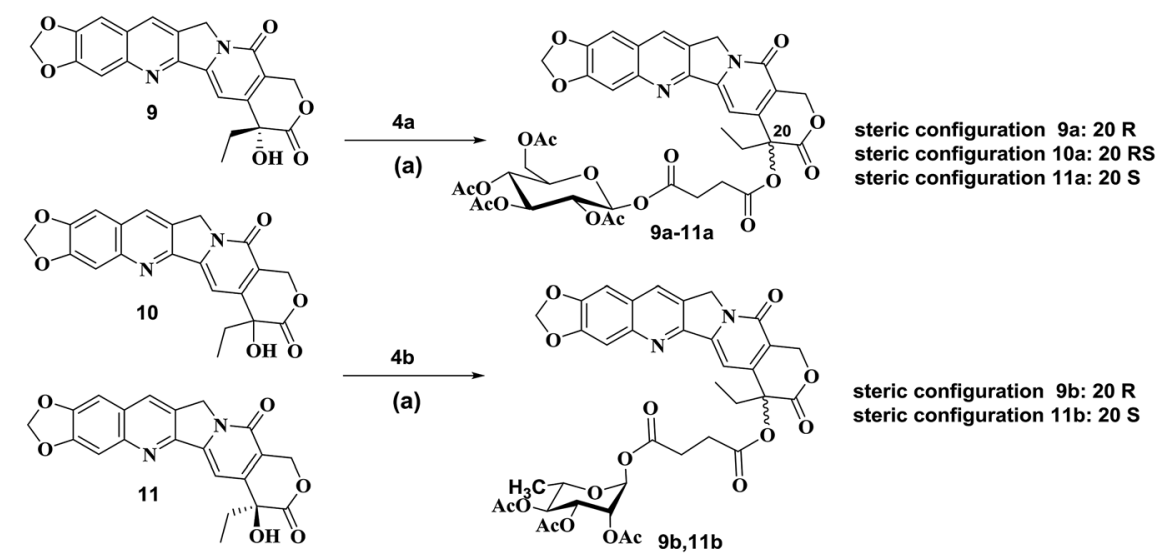

Scheme 1 Synthesis of compounds 9a-11a, 9b, 11b. Reagents and conditions: (a) EDCl, DMAP, $\mathrm{CH}_{2} \mathrm{Cl}_{2}$, reflux. 
Table $1 \quad I C_{50}$ values for the compounds in two human cancer cell lines (A549, MDA-MB-231) and the mouse prostate cancer cell lines (RM-1)

\begin{tabular}{lccl}
\hline & In vitro $\mathrm{IC}_{50}(\mathrm{nM})^{a}$ & & \\
\cline { 2 - 4 } Comp. & $\mathrm{A} 549$ & MDA-MB-231 & RM-1 \\
\hline 9a & $1612.50 \pm 276.48$ & $4527.40 \pm 174.66$ & $>1000$ \\
9b & $604.50 \pm 208.17$ & $1300.50 \pm 276.48$ & $>1000$ \\
10a & $102.18 \pm 33.41$ & $213.00 \pm 81.46$ & $>1000$ \\
11a & $135.80 \pm 61.10$ & $252.40 \pm 70.75$ & $>1000$ \\
11b & $83.34 \pm 11.04$ & $154.50 \pm 35.50$ & $48.27 \pm 6.25$ \\
FL118 & $8.94 \pm 1.54$ & $24.73 \pm 13.82$ & $69.19 \pm 8.34$ \\
Irinotecan & $9140.30 \pm 1054.87$ & $7817.50 \pm 2386.18$ & $>1000$
\end{tabular}

${ }^{a}$ Each $\mathrm{IC}_{50}$ value was calculated from 3 independent experiments performed in triplicate. Data are shown as mean \pm SD.

crucial for its activity. Activity of the pure $S$-configuration derivatives (11a and 11b) was higher than the pure $R$-configuration derivatives (9a and $\mathbf{9 b}$ ) in the two human cancer cell lines. In A549 cells, the mixture of $R$ - and $S$ - configuration derivative (10a) was the most active compound among the three compounds (9a, 10a, 11a). However, these compounds were less effective than FL118 in A549 and MDA-MB-231 cells. For RM-1 mouse prostate cancer cells, compounds $11 b\left(\mathrm{IC}_{50}: 48.27 \mathrm{nM}\right)$ showed the greatest cytotoxic effects, whilst the other glycoside compounds showed lower inhibitory activity at $1 \mu \mathrm{M}$ (Table 1 ).

\subsection{Effects of compound 11b on cell apoptosis}

To study how 11b affected the cell apoptosis, human lung cancer cells A549 were treated with FL118, irinotecan or 11b for $48 \mathrm{~h}$, respectively (Fig. 2). Specifically, the data revealed that treatment of cancer cells with 11b and FL118 resulted in the downregulation of survivin, while irinotecan treatment showed minimal effect on survivin. Furthermore, 11b and FL118 treatment increased the production of PARP cleavage in a concentration-dependent manner, which is the hallmark of apoptosis.

\subsection{Effects of compound $11 \mathrm{~b}$ on cell cycle}

Since survivin is a central molecule for normal cell cycle progression in most of cancer cells, we next tested how the compound 11b affected the cell cycles in the A549 lung cancer cells by flow cytometry analysis. When A549 cells were treated

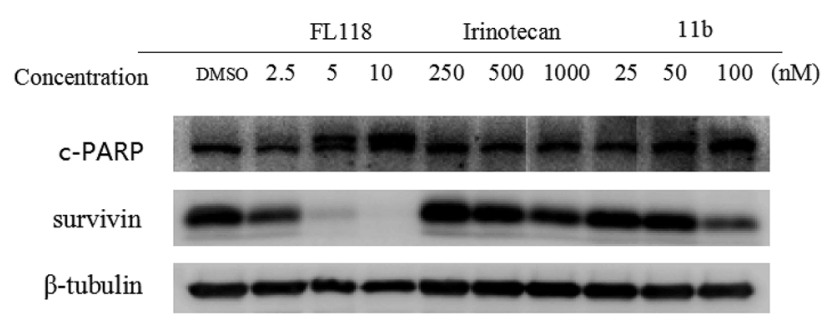

Fig. 2 Effects of compounds irinotecan, FL118 and 11b on cell apoptosis related proteins C-parp and survivin in A549 human lung cancer cells. The cells were seeded in $15 \mathrm{~cm}$ dishes for $24 \mathrm{~h}$, and then cells were treated with serial concentrations of three compounds, respectively. After $48 \mathrm{~h}$ of incubation, cells were harvested for western blotting analysis. $\beta$-Actin was served as an equal loading control. with $11 \mathrm{~b}$ from $25 \mathrm{nM}$ to $100 \mathrm{nM}$ for $48 \mathrm{~h}$, the population of cells in $\mathrm{G} 2 / \mathrm{M}$ phase dramatically increased as compared to that of vehicle (DMSO) group (Fig. 3A), along with concomitant losses in the G1 phase. As shown in Fig. 3B, compound FL118 at the concentrations of $2.5 \mathrm{nM}, 5 \mathrm{nM}$, and $10 \mathrm{nM}$ also increased $\mathrm{G} 2 / \mathrm{M}$ cell population in a concentration-dependent manner. The cell cycle data clearly showed compound $\mathbf{1 1 b}$ arrested A549 cells mainly at the G2/M phase.

\subsection{In vivo growth inhibition}

The in vivo antitumor efficacy of compound $\mathbf{1 1 b}$ was analyzed using RM-1 mouse model with transplantation of prostate cancer at doses of 3,6 and $9 \mathrm{mg} \mathrm{kg}^{-1}$ per dose. Treatment was initiated 10 days after subcutaneous tumor implantation when the individual tumors had grown to about $200-300 \mathrm{~mm}^{3}$. Compound 11b was administered by intratumoral injection to the mice (three times, every other day) for 7 days. As shown in Fig. 4, compound 11b showed superior antitumor activity in vivo at a dose of $9 \mathrm{mg} \mathrm{kg}^{-1}$, whilst this concentration was much lower than the clinical dose of irinotecan $\left(200 \mathrm{mg} \mathrm{kg}^{-1}\right)$ and topotecan (12.5 mg kg-1). Tumor growth inhibition (TGI) was calculated at the end of the treatment. Compound 11b demonstrated siginificant antitumor activity (TGI $=44.9 \%)$ at
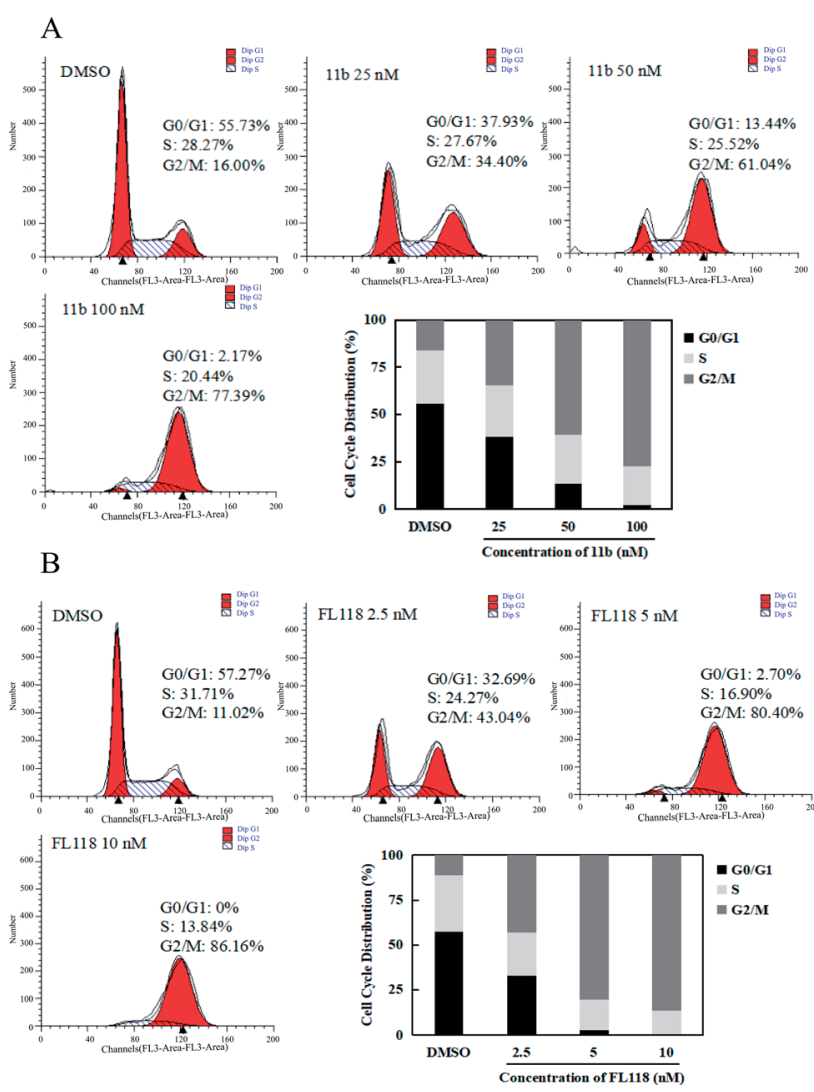

Fig. 3 A cell cycle distribution of A549 human lung cancer cells after treatments with compound $11 \mathrm{~b}$ (A) and FL118 (B). The cells were seeded in 6-well plates for $24 \mathrm{~h}$, and then the cells were treated with compound 11b or FL118. After 48 h of treatments, cells were harvested and subject to cell cycle analyses as described in the Experimental section. Statistical analysis was conducted among control and treated groups in G0/G1, S, and G2/M phases, separately. 
A

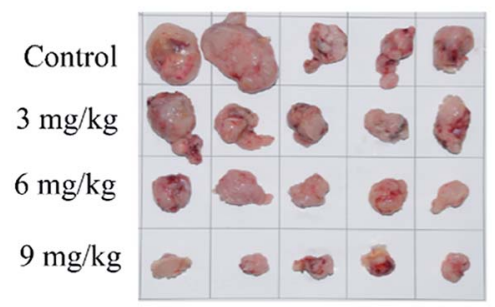

B

RM-1 prostate cancer model

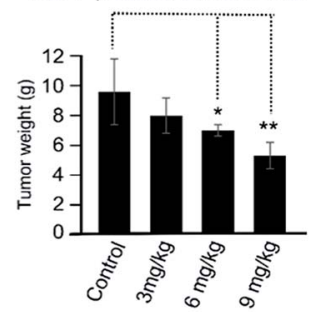

$\mathrm{C}$

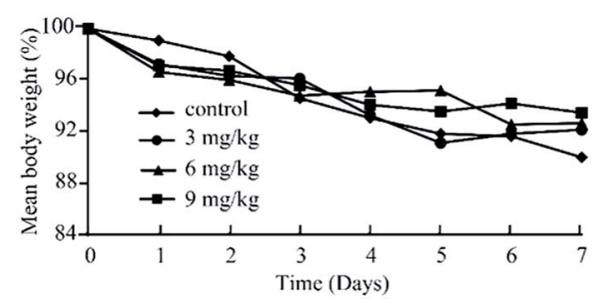

Fig. 4 In vivo antitumor effects of compound $11 \mathrm{~b}$ in the mouse prostate tumor of RM-1 cancer model. (A) Images of excised tumors in each group. (B) Weight of the excised tumors in each group $(* * * P<$ $0.001,{ }^{* *} P<0.01, * P<0.05$; Student's $t$-test). Data are expressed as the mean \pm standard deviation. (C) The mean mouse body weight curves derived from five mice treated with vehicle (control) or with one of the three doses of $11 \mathrm{~b}$. Of note, the standard error (SE) of body weight loss variation is within $10 \%$ among each group. a dose of $9 \mathrm{mg} \mathrm{kg}^{-1}$. It also can be seen from Fig. 4C that all the groups had nearly the same body weights, indicating the low toxicity of $\mathbf{1 1 b}$ toward mice.

\subsection{Molecule docking studies}

In order to understand the different molecular binding mechanism of compounds topotecan, FL118 and 11b in Top1/DNA complex, computational docking was performed using the Top1/DNA complex (PDB code: $1 \mathrm{~K} 4 \mathrm{~T}$ ). ${ }^{47}$ The docking study showed that the binding mode of topotecan was similar to that of the crystallographic topotecan in Top1/DNA complex (Fig. 5A), with a stacking interaction between 5-thio-2-deoxyguanosine phosphonic acid (TGP)/cytosine on one side of the ligand and a thymine base pair on the opposite side of the ligand. The topotecan interacts with Asp533, Arg364, Lys532 and a water molecule through a hydrogen bonding interaction. As shown in Fig. 5B, the predicted binding pose of FL118 is shown to have a similar disposition with respect to the interacting residues. The MOE docking energy of FL118 is about $1.28 \mathrm{kcal} \mathrm{mol}^{-1}$ higher than the SN-38 in the crystal structure suggesting that FL118 is significantly less active than the SN-38 for targeting the DNA topoisomerase I (Table S1†). ${ }^{10} 10,11$ Methylenedioxy-camptothecin rhamnoside 11b displayed an energetically less favourable binding mode with the Top1/DNA complex (Fig. 5C), which indicates 11b may also show lower topoisomerase I inhibition activity than topotecan.

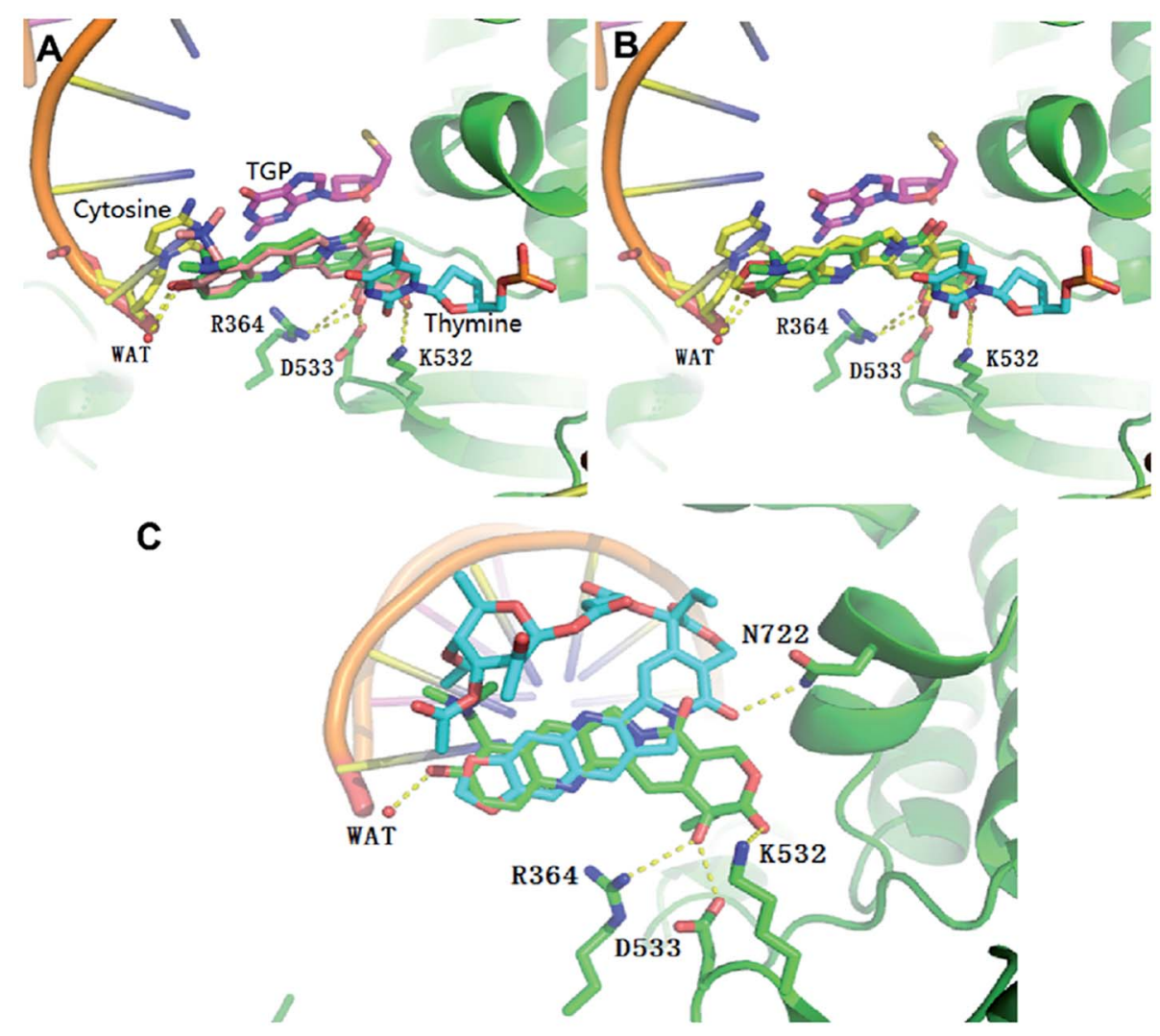

Fig. 5 Overlap of the binding mode of compounds topotecan (pink) (A), FL118 (yellow) (B), 11b (blue) (C) with the crystallographic topotecan (green) in Top1/DNA complex (PDB code: 1K4T). The oxygen, nitrogen, and sulfur atoms of compounds are shown in red, blue, and yellow, respectively. The side chains of the binding site are colored according to the atom types (carbon, green; oxygen, red; nitrogen, blue) and the hydrogen bonds are shown as dashed lines. The docking poses were visualized using PyMOL1.8. 
Table 2 Calculated ADMET descriptors related to absorption and distribution properties ${ }^{a}$

\begin{tabular}{lllrlll}
\hline Comp. & CNS & $\log$ HERG & PCaco & $\log B / B$ & PMDCK & F\% \\
\hline 9a & -2 & -5.213 & 159.608 & -2.027 & 68.069 & 44.6 \\
11a & -2 & -6.569 & 39.646 & -3.132 & 15.107 & 32.978 \\
9b & -2 & -6.666 & 68.091 & -2.827 & 27.106 & 41.469 \\
11b & -2 & -7.012 & 43.907 & -3.17 & 16.869 & 38.065
\end{tabular}

${ }^{a}$ CNS: -2 (inactive), +2 (active); log HERG $>-5$; PCaCo: $<25$ poor, $>500$ great; $\log B / B(-3-1.2)$; PMDCK: $<25$ poor, $>500$ great.

\subsection{In silico ADMET predictions}

Nowadays, the computational prediction of descriptors representing absorption, distribution, metabolism, excretion and toxicity properties (ADMET) are considered useful in silico tools, decreasing the proportion of drug candidates that can fail in clinical trials for ADMET reasons. Owing to the excellent in vitro activity, we initiated in silico calculations for ADMET prediction of compounds. As shown in Table 2, the predicted central nervous system (CNS) activity was computed on a -2 (inactive) to +2 (active) scale and showed that all these four compounds (9a, 11a, 9b and 11b) could be CNS inactive due to low values. The blood/brain partition coefficients $(\log B / B)$ were computed and also indicted all the four derivatives were difficult to access to the CNS. Human ether-a-go-go related gene (HERG) $\mathrm{K}^{+}$ channel blockers are potentially toxic. The recommended range for predicted $\log \mathrm{IC}_{50}$ values for blockage of HERG $\mathrm{K}^{+}$channels is $>-5$. The log HERG values $(-5.213$ to -7.012$)$ for compounds (9a, 11a, 9b and 11b) indicate that these compounds could show cardiac toxicity. Madin-Darby canine kidney (MDCK) monolayers are widely used to make oral absorption estimates. The values showed that compounds (9a, 11a, 9b and 11b) had poor MDCK cell permeability. However, all these four derivatives showed good Caco-2 permeability (PCaco).

\section{Conclusions}

In summary, a series of 20-substituted-10,11-methylenedioxycamptothecin glycoside derivatives were synthesized and their cytotoxic activities were evaluated against three tumor cell lines (A-549, MDA-MB-231, RM-1). All of the synthesized compounds showed superior cytotoxic activity to the irinotecan, but were less potent than FL118 in the two human cancer cell lines (A549 and MDA-MB-231). In the mouse prostate cancer cell model RM1, 10,11-methylenedioxy-camptothecin rhamnoside $\mathbf{1 1 b}$ displayed excellent activity with $\mathrm{IC}_{50}$ of $48.27 \mathrm{nM}$, which is lower than that for FL118 and irinotecan. Western blot analysis indicated 11b inhibited survivin expression and increased the expression of apoptotic marker PARP cleavage. Cell cycle analyses showed that 11b induced A549 lung cancer cell cycle arrest in a concentration-dependent manner. Molecular docking studies suggested that the binding mode of $\mathbf{1 1 b}$ was different from that of the crystal ligand topotecan in Top1/DNA complex. In addition, compound $\mathbf{1 1 b}$ exhibited significant antitumor effects in the RM-1 prostate cancer model in vivo (TGI $=44.9 \%$ ) at a dose of $9 \mathrm{mg} \mathrm{kg}^{-1}$. Overall, our findings provide strong evidence that FL118 is a promising scaffold for design of novel anti-tumor compounds with high anti-tumor efficacy.

\section{Experimental}

\subsection{Chemistry}

Materials and methods. All reagents used in the experiments were obtained from commercial sources and purified in a conventional manner. Column chromatography was performed using silica gel (200-300 mesh) purchased from MeiGao Ltd. (Qingdao, China). TLC was performed on a silica gel plate purchased from Merck Ltd. (Darmstadt, Germany). Melting points were determined with an X-4 digital micro melting point tester (Taike Ltd., Beijing, China) and were uncorrected. ${ }^{1} \mathrm{H}$ NMR, ${ }^{13} \mathrm{C}$ NMR spectra were acquired using Jeol JNM-ECP 600 spectrometer (Jeol Ltd., Tokyo, Japan) with tetramethylsilane $\left(\mathrm{Me}_{4} \mathrm{Si}\right)$ as the internal standard. Chemical shifts were recorded as $\delta$ values in $\mathrm{ppm}$. The following abbreviations were used: $\mathrm{s}=$ singlet, $\mathrm{d}=$ doublet, $\mathrm{t}=$ triplet, $\mathrm{q}=$ quartet, $\mathrm{m}=$ multiplet, $\mathrm{dd}$ $=$ double-doublet, $\mathrm{dt}=$ double-triplet, $\mathrm{tt}=$ triple-triplet. Mass spectra were recorded on a Q-TOF global mass spectrometer and the ionization method for all compounds below was electrospray ionization (ESI).

$\boldsymbol{\beta}$ - $\boldsymbol{O}$-(2,3,4,6-Tetra- $\boldsymbol{O}$-acetyl- $\boldsymbol{\beta}$-D-glucosyl)-succinic acid monoester $4 \mathbf{a}$. To a stirred solution of $3 \mathbf{a}(2 \mathrm{mmol})$ in dry THF $(20 \mathrm{~mL})$ was slowly added succinic anhydride $(3 \mathrm{mmol})$ and DMAP $(0.05 \mathrm{mmol})$ at room temperature. After being stirred for $24 \mathrm{~h}$, the solvent was removed on a rotary evaporator and EtOAc $(30 \mathrm{~mL})$ was poured into the residue. The solution was washed with $\mathrm{HCl}$ (1 M), brine, dried and concentrated. The oil was purified by flash chromatography on silica gel (petroleum ether/ ethyl acetate: $5 / 1$ ) to afford $\mathbf{4 a}$ as a colorless oily liquid with a 89\% yield. ${ }^{1} \mathrm{H}$ NMR (CHLOROFORM-D, $600 \mathrm{MHz}$ ) $\delta: 12.87$ (s, $1 \mathrm{H}), 5.64(\mathrm{~d}, J=7.6 \mathrm{~Hz}, 1 \mathrm{H}), 5.25(\mathrm{dd}, J=11.0,3.2 \mathrm{~Hz}, 1 \mathrm{H}), 5.15$ $(\mathrm{d}, J=3.7 \mathrm{~Hz}, 1 \mathrm{H}), 4.96(\mathrm{dd}, J=11.0,3.7 \mathrm{~Hz}, 1 \mathrm{H}), 4.35(\mathrm{t}, J=$ $6.4 \mathrm{~Hz}, 1 \mathrm{H}), 4.04(\mathrm{~m}, 2 \mathrm{H}), 2.96(\mathrm{t}, J=7.5 \mathrm{~Hz}, 2 \mathrm{H}), 2.48(\mathrm{t}, J=$ $7.5 \mathrm{~Hz}, 2 \mathrm{H}), 2.17(\mathrm{~s}, 3 \mathrm{H}), 2.10(\mathrm{~s}, 3 \mathrm{H}), 2.07(\mathrm{~s}, 3 \mathrm{H}), 2.03(\mathrm{~s}, 3 \mathrm{H})$.

$\alpha$-O-(2,3,4-Tri-O-acetyl- $\alpha$-L-rhamnosyl)-succinic acid monoester 4b. According to the same synthesis procedure of compound $\mathbf{4 a}$, compounds $\mathbf{4 b}$ were obtained as a colorless oily liquid in $87 \%$ yield. ${ }^{1} \mathrm{H}$ NMR (CHLOROFORM-D, $600 \mathrm{MHz}$ ) $\delta$ : 5.44 (dd, $J=10.6,3.3 \mathrm{~Hz}, 1 \mathrm{H}), 5.22(\mathrm{~m}, 1 \mathrm{H}), 5.09$ (t, $J=10.6 \mathrm{~Hz}$, $1 \mathrm{H}), 4.64(\mathrm{~d}, J=1.5 \mathrm{~Hz}, 1 \mathrm{H}), 3.98(\mathrm{~m}, 1 \mathrm{H}), 2.97(\mathrm{t}, J=6.5 \mathrm{~Hz}, 2 \mathrm{H})$, $2.58(\mathrm{t}, J=6.5 \mathrm{~Hz}, 2 \mathrm{H}), 2.16(\mathrm{~s}, 3 \mathrm{H}), 2.06(\mathrm{~s}, 3 \mathrm{H}), 2.00(\mathrm{~s}, 3 \mathrm{H}), 1.23$ (d, $J=5.9 \mathrm{~Hz}, 3 \mathrm{H})$.

\section{General procedure for the synthesis of 9-11}

Taking the 9 for example. A round bottom flask, 5 (1.06 g, 4 $\mathrm{mmol}), 6$ (1.2 g, $7.2 \mathrm{mmol})$ and 4-methylbenzenesulfonic acid $(0.16 \mathrm{~g}, 0.8 \mathrm{mmol})$ were dissolved in toluene $(200 \mathrm{~mL})$. Then the reaction mixture was refluxed under $\mathrm{N}_{2}$ atmosphere for $12 \mathrm{~h}$ at $110{ }^{\circ} \mathrm{C}$. The solvent was evaporated under reduced pressure and the residue was purified by flash chromatography on silica gel (dichloromethane/acetone: $3 / 1$ ) to afford pure product 9.

20-R-10,11-Methylenedioxycamptothecin 9. Yield: $80 \% ; \mathrm{mp}>$ $250{ }^{\circ} \mathrm{C} ;{ }^{1} \mathrm{H}$ NMR (DMSO- $\left.d_{6}, 500 \mathrm{MHz}\right) \delta 8.45(\mathrm{~s}, 1 \mathrm{H}), 7.49(\mathrm{~s}, 2 \mathrm{H})$, $7.24(\mathrm{~s}, 1 \mathrm{H}), 6.47(\mathrm{~s}, 1 \mathrm{H}), 6.27(\mathrm{~s}, 2 \mathrm{H}), 5.39$ (d, $J=16.5 \mathrm{~Hz}, 2 \mathrm{H})$, 5.20 (s, 2H), 1.90-1.79 (m, 2H), 0.91-0.81 (m, 3H); ${ }^{13} \mathrm{C}$ NMR 
(DMSO- $\left.d_{6}, 125 \mathrm{MHz}\right) \delta 172.3,157.3,151.8,150.5,150.4,149.1$, $147.0,146.4,130.6,128.89,126.1,118.5$, 105.3, 103.7, 103.0, 96.3, 72.9, 65.7, 50.6, 30.7, 8.2.

20-RS-10,11-Methylenedioxycamptothecin 10. Yield: 85\%; $\mathrm{mp}>250{ }^{\circ} \mathrm{C} ;{ }^{1} \mathrm{H}$ NMR $\left(\mathrm{CF}_{3} \mathrm{COOD}, 600 \mathrm{MHz}\right) \delta 9.03(\mathrm{~s}, 1 \mathrm{H}), 8.17$ $(\mathrm{s}, 1 \mathrm{H}), 7.70(\mathrm{~s}, 1 \mathrm{H}), 7.57(\mathrm{~s}, 1 \mathrm{H}), 6.43(\mathrm{~s}, 2 \mathrm{H}), 5.72(\mathrm{~s}, 2 \mathrm{H}), 5.56(\mathrm{~s}$, $2 \mathrm{H}), 2.14$ (q, $J=7.1 \mathrm{~Hz}, 2 \mathrm{H}), 1.12(\mathrm{t}, J=7.1 \mathrm{~Hz}, 3 \mathrm{H}) ;{ }^{13} \mathrm{C}$ NMR $\left(\mathrm{CF}_{3} \mathrm{COOD}, 151 \mathrm{MHz}\right) \delta 172.5,159.8,158.7,156.9,151.0,149.9$, 145.5, 144.9, 143.7, 130.4, 128.7, 119.9, 106.1, 104.6, 101.2, 97.5, $72.9,65.7,51.2,30.3,7.7$.

20-S-10,11-Methylenedioxycamptothecin 11. Yield: $81 \%$; $\mathrm{mp}$ $>250{ }^{\circ} \mathrm{C} ;{ }^{1} \mathrm{H}$ NMR $\left(\mathrm{CF}_{3} \mathrm{COOD}, 600 \mathrm{MHz}\right) \delta 9.05(\mathrm{~s}, 1 \mathrm{H}), 8.16(\mathrm{~s}$, $1 \mathrm{H}), 7.69$ (s, 1H), 7.55 (s, 1H), $6.44(\mathrm{~s}, 2 \mathrm{H}), 5.93$ (d, $J=16.6 \mathrm{~Hz}$, $1 \mathrm{H}), 5.73(\mathrm{~s}, 2 \mathrm{H}), 5.60(\mathrm{~d}, J=16.6 \mathrm{~Hz}, 1 \mathrm{H}), 2.16(\mathrm{~d}, J=6.6 \mathrm{~Hz}$, $2 \mathrm{H}), 1.15(\mathrm{~s}, 3 \mathrm{H}) ;{ }^{13} \mathrm{C}$ NMR $\left(\mathrm{CF}_{3} \mathrm{COOD}, 151 \mathrm{MHz}\right) \delta 178.8,161.1$, $155.5,153.9$, 143.5, 142.2, 141.5, 132.1, 131.9, 124.6, 107.7, $106.5,102.4,99.5,76.4,68.9,54.3,33.7,8.4$.

General procedure for the synthesis of $9 a-11 a, 9 b, 11 b$

Taking the $9 a$ for example. To a stirred solution of $9(0.25$ $\mathrm{mmol})$ in dry DCM (40 mL) was added EDCI (2.2 mmol), DMAP $(0.51 \mathrm{mmol})$ and $4 \mathrm{a}(1.0 \mathrm{mmol})$ at room temperature. Then the reaction mixture was refluxed under $\mathrm{N}_{2}$ atmosphere for $12 \mathrm{~h}$ at $40{ }^{\circ} \mathrm{C}$. The mixture was cooled down to room temperature and DCM $(30 \mathrm{~mL})$ was poured into the mixture. The solution was washed with $\mathrm{HCl}(1 \mathrm{M})$, brine, dried over anhydrous $\mathrm{Na}_{2} \mathrm{SO}_{4}$ and concentrated under reduced pressure to provided colorless oily and concentrated under reduced pressure. The residue was purified by flash chromatography on silica gel (dichloromethane/acetone: $5 / 1$ ) to afford white powder 9a.

$\left(2^{\prime}, 3^{\prime}, 4^{\prime}, 6^{\prime}\right.$-Tetra- $O$-acetyl- $\beta$-D-glucosyl)-succinic acid-10,11methylenedioxy-camptothecin-20(R)-O-ester 9a. Yield: $68 \%$; mp $138-139{ }^{\circ} \mathrm{C} ;[\alpha]_{\mathrm{D}}^{14}=284.25^{\circ}\left(c=0.4 \mathrm{mg} \mathrm{mL}^{-1}, \mathrm{CH}_{3} \mathrm{OH}\right) ;{ }^{1} \mathrm{H} \mathrm{NMR}$ (DMSO- $\left.d_{6}, 500 \mathrm{MHz}\right) \delta 8.43(\mathrm{~s}, 1 \mathrm{H}), 7.47(\mathrm{~d}, J=9.8 \mathrm{~Hz}, 2 \mathrm{H}), 6.98$ $(\mathrm{s}, 1 \mathrm{H}), 6.28(\mathrm{~d}, J=4.8 \mathrm{~Hz}, 2 \mathrm{H}), 6.24(\mathrm{~d}, J=7.8 \mathrm{~Hz}, 1 \mathrm{H}), 5.45(\mathrm{~d}, J$ $=2.6 \mathrm{~Hz}, 2 \mathrm{H}), 5.32(\mathrm{t}, J=9.9 \mathrm{~Hz}, 1 \mathrm{H}), 5.18(\mathrm{~s}, 2 \mathrm{H}), 5.06-4.97(\mathrm{~m}$, $2 \mathrm{H}), 4.17-4.06(\mathrm{~m}, 2 \mathrm{H}), 3.90(\mathrm{~d}, J=11.6 \mathrm{~Hz}, 1 \mathrm{H}), 2.92-2.69(\mathrm{~m}$, $5 \mathrm{H}), 2.14$ (tt, $J=13.9,7.1 \mathrm{~Hz}, 2 \mathrm{H}), 1.97-1.93$ (m, 10H), 1.26-1.20 $(\mathrm{m}, 1 \mathrm{H}), 0.90(\mathrm{t}, J=7.3 \mathrm{~Hz}, 3 \mathrm{H}) ;{ }^{13} \mathrm{C}$ NMR (DMSO- $d_{6}, 126 \mathrm{MHz}$ ) $\delta 171.3,170.7,170.4,170.1,170.0,169.6,167.6,157.0,151.8$, 150.2 , 149.1, 147.0, 146.9, 145.6, 130.6, 128.8, 126.1, 118.4, 105.2, 103.6, 103.1, 94.6, 89.0, 76.6, 69.7, 69.6, 69.1, 67.7, 66.8, 61.5, 50.6, 30.9, 28.8, 20.8, 20.8, 20.7, 20.6, 8.0. HRMS (ESI-TOF, $\left.[\mathrm{M}+\mathrm{H}]^{+}\right): m / z$ calcd for $\mathrm{C}_{39} \mathrm{H}_{38} \mathrm{~N}_{2} \mathrm{O}_{18}, 823.7290$; found, 823.2191.

$\left(2^{\prime}, 3^{\prime}, 4^{\prime}, 6^{\prime}\right.$-Tetra- $O$-acetyl- $\beta$-D-glucosyl)-succinic acid-10,11methylenedioxy-camptothecin-20(RS)-O-ester 10a. Yield: 63\%; $\operatorname{mp} 160-163{ }^{\circ} \mathrm{C} ;[\alpha]_{\mathrm{D}}^{14}=32.75^{\circ}\left(c=0.4 \mathrm{mg} \mathrm{mL}{ }^{-1}, \mathrm{CH}_{3} \mathrm{OH}\right) ;{ }^{1} \mathrm{H}$ NMR (DMSO- $\left.d_{6}, 600 \mathrm{MHz}\right) \delta: 8.41(\mathrm{~s}, 1 \mathrm{H}), 7.50-7.46(\mathrm{~s}, 1 \mathrm{H}), 7.42$ $(\mathrm{s}, 1 \mathrm{H}), 6.96(\mathrm{~s}, 1 \mathrm{H}), 6.29-6.22(\mathrm{~m}, 2 \mathrm{H}), 6.20(\mathrm{t}, J=4.4 \mathrm{~Hz}, 1 \mathrm{H})$, 5.41 (dd, $J=13.7,6.5 \mathrm{~Hz}, 2 \mathrm{H}), 5.25$ (t, $J=9.9 \mathrm{~Hz}, 1 \mathrm{H}), 5.16$ (s, $2 \mathrm{H}), 4.99(\mathrm{t}, J=9.7 \mathrm{~Hz}, 1 \mathrm{H}), 4.81(\mathrm{dd}, J=10.2,3.7 \mathrm{~Hz}, 1 \mathrm{H}), 4.14-$ 4.08 (m, 2H), 3.98-3.92 (m, 1H), 2.90-2.85 (m, 1H), 2.80-2.73 $(\mathrm{m}, 2 \mathrm{H}), 2.72-2.67(\mathrm{~m}, 1 \mathrm{H}), 2.14-2.05(\mathrm{~m}, 1 \mathrm{H}), 1.97-1.86(\mathrm{~m}$, 9H), 1.72-1.66 (m, 3H), 0.90-0.84 (m, 3H).; ${ }^{13} \mathrm{C}$ NMR (DMSO- $d_{6}$, $150 \mathrm{MHz}) \delta: 171.3,170.9,170.4,170.0,169.7,169.5,167.6,157.0$, $151.9,150.2,149.2,147.0,146.8,145.7,130.6,128.8,126.2$, 118.3, 105.1, 103.6, 103.1, 94.6, 89.0, 76.6, 69.6, 69, 68.9, 67.7, $66.7,61.5,50.5,30.8,28.9,28.8,20.9,20.7,20.2$, 8.0, 0.6. HRMS
(ESI-TOF, $[\mathrm{M}+\mathrm{H}]^{+}$): $m / z \quad \mathrm{C}_{39} \mathrm{H}_{38} \mathrm{~N}_{2} \mathrm{O}_{18}, 823.2192$; found, 823.2193 .

$\left(2^{\prime}, 3^{\prime}, 4^{\prime}, 6^{\prime}\right.$-Tetra- $O$-acetyl- $\beta$-D-glucosyl)-succinic acid-10,11methylenedioxy-camptothecin-20 $(S)$-O-ester 11a. Yield: $61 \%$; $\operatorname{mp} 196{ }^{\circ} \mathrm{C} ;[\alpha]_{\mathrm{D}}^{14}=-27.75^{\circ}\left(c=0.4 \mathrm{mg} \mathrm{mL}^{-1}, \mathrm{CH}_{3} \mathrm{OH}\right) ;{ }^{1} \mathrm{H} \mathrm{NMR}$ $\left(\mathrm{DMSO}-d_{6}, 500 \mathrm{MHz}\right) \delta 8.45(\mathrm{~s}, 1 \mathrm{H}), 7.51(\mathrm{~s}, 1 \mathrm{H}), 7.45(\mathrm{~s}, 1 \mathrm{H}), 6.99$ $(\mathrm{s}, 1 \mathrm{H}), 6.28(\mathrm{~d}, J=7.6 \mathrm{~Hz}, 2 \mathrm{H}), 6.22(\mathrm{~d}, J=7.8 \mathrm{~Hz}, 1 \mathrm{H}), 5.43$ (dd, $J=17.8,6.3 \mathrm{~Hz}, 2 \mathrm{H}), 5.28(\mathrm{t}, J=9.9 \mathrm{~Hz}, 1 \mathrm{H}), 5.21(\mathrm{~s}, 2 \mathrm{H}), 5.02(\mathrm{t}$, $J=9.6 \mathrm{~Hz}, 1 \mathrm{H}), 4.84(\mathrm{dd}, J=10.3,3.6 \mathrm{~Hz}, 1 \mathrm{H}), 4.14(\mathrm{~d}, J=9.8 \mathrm{~Hz}$, $2 \mathrm{H}), 3.99(\mathrm{t}, J=10.7 \mathrm{~Hz}, 1 \mathrm{H}), 2.90(\mathrm{dt}, J=18.8,9.3 \mathrm{~Hz}, 1 \mathrm{H}), 2.84-$ $2.68(\mathrm{~m}, 3 \mathrm{H}), 2.18-2.08(\mathrm{~m}, 2 \mathrm{H}), 2.01-1.86(\mathrm{~m}, 9 \mathrm{H}), 1.73(\mathrm{~s}, 3 \mathrm{H})$, 0.90 (q, $J=7.2 \mathrm{~Hz}, 3 \mathrm{H}) ;{ }^{13} \mathrm{C}$ NMR (DMSO- $\left.d_{6}, 126 \mathrm{MHz}\right) \delta 171.3$, $170.9,170.4,170.0,169.7,169.5$, 167.6, 157.0, 151.9, 150.2, 149.2 , 147.0, 146.8, 145.7, 130.6, 128.8, 126.2, 118.3, 105.1, 103.6, 103.1, 94.8, 89.1, 76.6, 69.7, 69.7, 69.0, 67.7, 66.7, 61.5, 50.6, 30.8, 28.9, 28.8, 20.9, 20.7, 20.2, 8.0. HRMS (ESI-TOF, [M + $\left.\mathrm{H}]^{+}\right): m / z$ calcd for $\mathrm{C}_{39} \mathrm{H}_{38} \mathrm{~N}_{2} \mathrm{O}_{18}, 823.7290$; found, 823.2196.

$\left(2^{\prime}, 3^{\prime}, 4^{\prime}\right.$-Tri-O-acetyl- $\alpha$-L-rhamnosyl)-succinic acid-10,11methylenedioxy-camptothecin-20(R)-O-ester $9 \mathrm{~b}$. Yield: 71\%; mp $177-178{ }^{\circ} \mathrm{C} ;[\alpha]_{\mathrm{D}}^{14}=98.75^{\circ}\left(c=0.4 \mathrm{mg} \mathrm{mL}^{-1}, \mathrm{CH}_{3} \mathrm{OH}\right) ;{ }^{1} \mathrm{H} \mathrm{NMR}$ (DMSO- $\left.d_{6}, 500 \mathrm{MHz}\right) \delta 8.42(\mathrm{~s}, 1 \mathrm{H}), 7.49-7.42(\mathrm{~m}, 2 \mathrm{H}), 7.02(\mathrm{~d}, J$ $=5.4 \mathrm{~Hz}, 1 \mathrm{H}), 6.28(\mathrm{~d}, J=9.3 \mathrm{~Hz}, 2 \mathrm{H}), 5.94(\mathrm{~s}, 1 \mathrm{H}), 5.46(\mathrm{~s}, 2 \mathrm{H})$, 5.19-5.11 (m, 3H), 5.07 (s, 1H), 4.89 (t, J=10.0 Hz, 1H), 3.97 (dt, $J=12.4,6.2 \mathrm{~Hz}, 1 \mathrm{H}), 2.89-2.70$ (m, 4H), 2.18-2.06 (m, 3H), 2.03$1.99(\mathrm{~m}, 3 \mathrm{H}), 1.96(\mathrm{~s}, 2 \mathrm{H}), 1.91(\mathrm{~d}, J=6.2 \mathrm{~Hz}, 3 \mathrm{H}), 1.09(\mathrm{~d}, J=$ $6.1 \mathrm{~Hz}, 3 \mathrm{H}$ ), 0.91 (t, $J=7.4 \mathrm{~Hz}, 3 \mathrm{H}$ ); ${ }^{13} \mathrm{C}$ NMR (DMSO- $d_{6}, 126$ $\mathrm{MHz}) \delta 171.3,170.2,170.1,169.9,169.8,167.6,157.0,151.8$, 150.2 , 149.1, 147.0, 146.8, 145.7, 130.6, 128.8, 126.1, 118.3, 105.2, 103.5, 103.1, 94.8, 90.7, 76.6, 70.3, 70.2, 68.6, 68.5, 68.4, 66.7, 50.5, 30.8, 28.9, 20.9, 20.8, 20.8, 17.7, 8.0. HRMS (ESI-TOF, $\left.[\mathrm{M}+\mathrm{H}]^{+}\right): m / z$ calcd for $\mathrm{C}_{37} \mathrm{H}_{36} \mathrm{~N}_{2} \mathrm{O}_{16}, 765.6930$; found, 765.2142.

$\left(2^{\prime}, 3^{\prime}, 4^{\prime}\right.$-Tri-O-acetyl- $\alpha$-L-rhamnosyl)-succinic acid-10,11methylenedioxy-camptothecin-20(S)-O-ester 11b. Yield: 73\%; $\mathrm{mp} 202-203{ }^{\circ} \mathrm{C} ;[\alpha]_{\mathrm{D}}^{14}=-166.50^{\circ}\left(c=0.4 \mathrm{mg} \mathrm{mL}{ }^{-1}, \mathrm{CH}_{3} \mathrm{OH}\right) ;{ }^{1} \mathrm{H}$ NMR (DMSO- $\left.d_{6}, 500 \mathrm{MHz}\right) \delta 8.42(\mathrm{~s}, 1 \mathrm{H}), 7.46(\mathrm{~d}, J=9.1 \mathrm{~Hz}, 2 \mathrm{H})$, $6.94(\mathrm{~s}, 1 \mathrm{H}), 6.28(\mathrm{~d}, J=9.0 \mathrm{~Hz}, 2 \mathrm{H}), 6.05(\mathrm{~s}, 1 \mathrm{H}), 5.44(\mathrm{~d}, J=$ $16.7 \mathrm{~Hz}, 2 \mathrm{H}), 5.20-5.12(\mathrm{~m}, 4 \mathrm{H}), 4.90(\mathrm{t}, J=9.7 \mathrm{~Hz}, 1 \mathrm{H}), 3.96(\mathrm{dq}$, $J=12.3,6.1 \mathrm{~Hz}, 1 \mathrm{H}), 2.89(\mathrm{dt}, J=16.6,6.4 \mathrm{~Hz}, 1 \mathrm{H}), 2.81(\mathrm{dd}, J=$ $14.5,8.4 \mathrm{~Hz}, 1 \mathrm{H}), 2.79-2.71(\mathrm{~m}, 2 \mathrm{H}), 2.20-2.08(\mathrm{~m}, 2 \mathrm{H}), 2.04-$ $1.89(\mathrm{~m}, 9 \mathrm{H}), 1.02(\mathrm{t}, J=7.0 \mathrm{~Hz}, 3 \mathrm{H}), 0.91(\mathrm{t}, J=7.4 \mathrm{~Hz}, 3 \mathrm{H}) ;{ }^{13} \mathrm{C}$ NMR (DMSO- $\left.d_{6}, 126 \mathrm{MHz}\right) \delta 171.2,170.2,170.1,170.0,169.9$, 167.6 , 157.0, 151.8, 150.2, 149.1, 147.0, 146.8, 145.6, 130.6, 128.8, 126.1, 118.3, 105.1, 103.6, 103.1, 94.7, 90.6, 76.6, 70.1, 68.6, 68.6, 68.4 , 66.7, 50.5, 30.8, 29.0, 29.0, 20.9, 20.9, 20.8, 17.5, 8.0. HRMS (ESI-TOF, $[\mathrm{M}+\mathrm{H}]^{+}$): calcd for $\mathrm{C}_{37} \mathrm{H}_{36} \mathrm{~N}_{2} \mathrm{O}_{16}, 765.6930$; found, 765.2138.

\subsection{Bioactivity study}

Cell culture. The human ovarian cancer cell line 2008, the human lung cancer cell line A549, the human breast cancer cell line MDA-MB-231 and the mouse prostate cancer cell line RM-1, were obtained from the Type Culture Collection of the Chinese Academy of Sciences (Shanghai, China). A2008, A549, MDA-MB231 and RM-1 cells were maintained in RPMI 1640 media (Gibco) supplemented with 5\% heat-inactivated FBS (Gibco, Australia), $100 \mathrm{U} \mathrm{mL}^{-1}$ of penicillin, and $0.1 \mathrm{mg} \mathrm{mL}^{-1}$ of 
streptomycin (hyclone) at $37{ }^{\circ} \mathrm{C}$ with $5 \% \mathrm{CO}_{2}$ and $95 \%$ air. Cells were maintained at subconfluency and culture media were changed every other day. All cells used were between passages 3 to 30 . DMSO was used as the vehicle to deliver the compounds at a final concentration of $0.1 \%$ in all of the experiments.

Cellular viability assay and $\mathbf{I C}_{50}$ calculations. For cellular viability assay, a 96-wells plate was seeded with 2000 cells per well in $100 \mu \mathrm{L}$ of complete cell culture medium. After 24 hours, $100 \mu \mathrm{L}$ of complete medium containing serial concentrations of each compound was added to each well. Either cancer or $\mathrm{CHO}$ cells were cultured for 48 hours, followed by addition of $20 \mu \mathrm{L}$ of resazurin ( $2 \mathrm{mg} \mathrm{mL}^{-1}$ dissolved in water, catalog no. R7017-5 G, Sigma) to the media for 16 hours. The fluorescent signal was monitored at an excitation wavelength of $544 \mathrm{~nm}$ and an emission wavelength of $595 \mathrm{~nm}$ using a Spectramax M5 plate reader (Molecular Devices). The relative fluorescence unit (RFU) generated from the assay was proportional to the number of living cells in each well. ${ }^{48}$ The IC $_{50}$ values for each drug were calculated using the Logit approach.

Immunoblot analysis. A549 cells were seeded in $15 \mathrm{~cm}$-petri dishes $(8 \times 104$ cells per $\mathrm{mL}, 20 \mathrm{~mL}$ per dish). After $24 \mathrm{~h}$, cells were treated with serial concentrations of compound FL118, irinotecan and $\mathbf{1 1 b}$. After another $48 \mathrm{~h}$ of incubation at $37^{\circ} \mathrm{C}$, all the cells were collected with cell-scrapers, and incubated on ice for $30 \mathrm{~min}$ in cell lysis buffer (Cell Signaling Technology, USA). Cell suspensions were centrifugated at $10000 \times g$ for $10 \mathrm{~min}$ at $4{ }^{\circ} \mathrm{C}$, then supernatants were collected. Proteins were quantified by BCA Protein Assay Kit (Beyotime, Beijing, China). For immunoblot analysis, equal amount of proteins $(25-100 \mu \mathrm{g}$, depending on the proteins of interest) were resolved over $10 \%$ or $12 \%$ SDS-polyacrylamide gel electrophoresis and transferred to nitrocellulose membrane. The membranes containing the transferred protein were blocked in blocking buffer (5\% nonfat dry milk, $1 \%$ Tween-20 in $20 \mathrm{mM}$ Tris-buffered saline, $\mathrm{pH} 7.6$ ) for $2 \mathrm{~h}$ at room temperature, and then incubated with appropriate monoclonal primary antibody in blocking buffer overnight at $4{ }^{\circ} \mathrm{C}$. After incubation with appropriate secondary antibodies, the membranes were washed three times with Tris buffer with Tween-20, and then visualized using Western Lightning (PerkinElmer, Waltham, MA, USA). Antibody for survivin was purchased from Santa Cruz. Antibody for PARP was purchased from Cell Signaling.

Cell cycle analyses. A549 $\left(6 \times 10^{4}\right.$ cell per $\left.\mathrm{mL}\right)$ cells were seeded in 6-well plates. Gentle mixing was required to avoid accumulation of cells in the center of each well. After $24 \mathrm{~h}$ of incubation for attachment, cells were treated with serial concentrations of compound 11b or FL118 in $2 \mathrm{~mL}$ of serum complete media. After $48 \mathrm{~h}$, media containing any floating cells were collected and combined with adherent cells that were detached by brief trypsinization (0.25\% trypsin-EDTA; hyclone). Cell pellets were washed with $1 \mathrm{~mL}$ of ice-cold PBS and then resuspended in $1 \mathrm{~mL}$ of $70 \%$ ethanol and then kept at $4{ }^{\circ} \mathrm{C}$ overnight. After centrifugation $(1600 \times g, 5 \mathrm{~min})$, the supernatant was removed and the cells were incubated with $0.5 \mathrm{~mL} \mathrm{PI} /$ RNase staining buffer (BD Biosciences) for $15 \mathrm{~min}$ at room temperature. Single-cell suspension was generated by gentle pipetting. Cell cycle was analyzed using the Beckman cell analyzer FC500-mpl at Marine Biodiversity and Evolutionary Institute (Ocean University of China), and data were processed using Beckman CXP software and Multicycle software.

In Vivo antitumor activity. The in vivo antitumor activity of compound 11b was determined in the RM-1 mouse prostate cancer model. All animal procedures were performed in accordance with the Guidelines for Care and Use of Laboratory Animals of School of Medicine and Pharmacy, Ocean University of China and approved by the Animal Ethics Committee of School of Medicine and Pharmacy, Ocean University of China. Five-week-old male C57BL6 mice were subcutaneously inoculated with a small RM-1 tumor block on the back of the mouse. The animals were randomized into the appropriate experimental groups (five animals for the control and for each treatment group). When the tumor volume reached $200-300 \mathrm{~mm}^{3}$, drugs were administered by intratumoral injection (three doses, every other day on three occasions) for 7 days. The drug was formulated in a mixture of 5\% DMSO, 4\% Tween 80, and $81 \%$ normal saline. Body weights were recorded every day after drug treatment. At the end of the observation period, animals were euthanized by cervical dislocation and the tumor bulks were peeled off according to the Guide for the Care and Use of Laboratory Animals as published by the US National Institutes of Health (NIH Publication No. 85-23, revised 1996) and approved by the Institutional Ethics Review Board of Sun YatSen University, and the case number is IACUC-DD-17-0505.

\subsection{Molecular modeling}

Molecular docking was performed using MOE using AMBER10:EHT forcefield. Compounds topotecan, FL118 and 11b were drawn in Chem3D Pro saved the format as mol2 and minimized using 10000 steps of steepest minimization in MOE. The X-ray crystal structures of the Top1/DNA complex (PDB code: 1K4T) was downloaded from the protein data bank (http://www.rcsb.org). In consideration of the flexibility of the side chains of the residues at the binding site, the induced fit docking approach was applied in the docking studies. The produced conformation of with the best score was selected for the analysis.

\subsection{ADMET predictions}

The prediction of ADMET properties were performed using the Advanced Chemistry Development (ACD) Percepta platform (http://www.acdlabs.com). Any ADMET descriptor was evaluated by Percepta based on training libraries implemented in the software, which include a consistent pool of molecules whose pharmacokinetic and toxicity profiles are experimentally known.

\section{Conflicts of interest}

The authors declare no competing financial interest.

\section{Acknowledgements}

The authors are grateful for financial support granted by National Science and Technology Major Project of China 
(2018ZX09735-004), NSFC-Shandong Joint Fund (U1706213, U1406403), the Fundamental Research Funds for the Central Universities (No. 201512007, 201762011 for R. Y.), Innovation Project from Qingdao National Laboratory for Marine Science and Technology (No. 2015ASKJ02), the Marine S\&T Fund of Shandong Province (No. 2018SDKJ0403) and Taishan Scholar Project Fund of Shandong Province (TS201511011).

\section{Notes and references}

1 M. E. Wall, M. C. Wani, C. E. Cook, K. H. Palmer, A. T. Mcphail and G. A. Sim, J. Med. Chem., 1966, 88, 38883890.

2 S. T. Liew and L. X. Yang, Curr. Pharm. Des., 2008, 14, 10781097.

3 Q. Y. Li, Y. G. Zu, R. Z. Shi and L. P. Yao, Curr. Med. Chem., 2006, 13, 2021-2039.

4 M. C. Chen, N. H. Lee, T. J. Ho, H. H. Hsu, C. H. Kuo, W. W. Kuo, Y. M. Lin, F. J. Tsai, C. H. Tsai and C. Y. Huang, Cancer Lett., 2014, 349, 51-60.

5 Y. Bessho, T. Oguri, H. Achiwa, H. Muramatsu, H. Maeda, T. Niimi, S. Sato and R. Ueda, Cancer Sci., 2006, 97, 192-198.

6 M. Leggas, M. Adachi, G. L. Scheffer, D. Sun, P. Wielinga, G. Du, K. E. Mercer, Y. Zhuang, J. C. Panetta, B. Johnston, R. J. Scheper, C. F. Stewart and J. D. Schuetz, Mol. Cell. Biol., 2004, 24, 7612-7621.

7 W. Cruz-Muñoz, T. Di. Desidero, S. Man, P. Xu, M. L. Jaramillo, K. Hashimoto, C. Collins, M. Banville, M. D. O'Connor-McCourt and R. S. Kerbel, Angiogenesis, 2014, 17, 661-673.

8 J. Nemunaitis, J. Cox, W. Meyer, A. Courtney and G. Mues, Am. J. Clin. Oncol., 1997, 20, 527-529.

9 B. Saraiya, M. Gounder, J. Dutta, A. Saleem, C. Collazo, L. Zimmerman, A. Nazar, M. Gharibo, D. Schaar, Y. Lin, W. Shih, J. Aisner, R. K. Strair and E. H. Rubin, Anticancer Drugs, 2008, 19, 411-420.

10 X. Ling, S. Cao, Q. Cheng, J. T. Keefe, Y. M. Rustum and F. Li, PLoS One, 2012, 7, e45571.

11 F. Li, E. J. Ackermann, C. F. Bennett, A. L. Rothermel, J. Plescia, S. Tognin, A. Villa, P. C. Marchisio and D. C. Altieri, Nat. Cell Biol., 1999, 1, 461-466.

12 M. J. Yoon, S. S. Park, Y. J. Kang, I. Y. Kim, J. A. Lee, J. S. Lee, E. G. Kim, C. W. Lee and K. S. Choi, Carcinogenesis, 2012, 33, 492-500.

13 S. Trabulo, A. M. Cardoso, T. Santos-Ferreira, A. L. Cardoso, S. Simões and M. C. Pedroso de Lima, Mol. Pharm., 2011, 8, 1120-1131.

14 K. M. Rahman, S. Banerjee and S. Ali, Cancer Res., 2009, 69, 4468-4475.

15 F. Li and X. Ling, J. Cell. Physiol., 2006, 208, 476-486.

16 F. Rödel, J. Hoffmann, L. Distel, M. Herrmann, T. Noisternig, T. Papadopoulos, R. Sauer and C. Rödel, Cancer Res., 2005, 65, 4881-4887.

17 B. Z. Carter, D. H. Mak, W. D. Schober, M. Cabreira-Hansen, M. Beran, T. McQueen, W. Chen and M. Andreeff, Blood, 2006, 107, 1555-1563.
18 J. Wu, X. Ling, D. Pan, P. Apontes, L. Song, P. Liang, D. C. Altieri, T. Beerman and F. Li, J. Biol. Chem., 2005, 280, 9745-9751.

19 T. Saito, S. Hama, H. Izumi, F. Yamasaki, Y. Kajiwara, S. Matsuura, K. Morishima, T. Hidaka, P. Shrestha, K. Sugiyama and K. Kurisu, Br. J. Cancer, 2008, 98, 345-355.

20 M. Zhang, D. E. Latham, M. A. Delaney and A. Chakravarti, Oncogene, 2005, 24, 2474-2482.

21 R. Hernan, V. Zachary and K. J. Pienta, J. Biol. Chem., 2008, 283, 25057-25073.

22 M. Vogler, H. Walczak, D. Stadel, T. L. Haas, F. Genze, M. Jovanovic, J. E. Gschwend, T. Simmet, K. M. Debatin and S. Fulda, Cancer Res., 2008, 68, 7956-7965.

23 X. Ding, A. B. Mohd, Z. Huang, T. Baba, M. Q. Bernardini, H. K. Lyerly, A. Berchuck, S. K. Murphy, A. B. Buermeyer and G. R. Devi, Br. J. Cancer, 2009, 101, 269-277.

24 K. Connolly, R. Mitter, M. Muir, D. Jodrell and S. Guichard, Cancer Chemother. Pharmacol., 2009, 64, 307-316.

25 X. He, A. Khurana, J. L. Maguire, J. Chien and V. Shridhar, Int. J. Cancer, 2012, 130, 1029-1035.

26 O. Ndozangue-Touriguine, M. Sebbagh, D. Mérino, O. Micheau, J. Bertoglio and J. A. Bréard, Oncogene, 2008, 27, 6012-6022.

27 X. Zhao, T. Laver, S. W. Hong, G. B. Jr Twitty, A. Devos, M. Devos, E. N. Benveniste and S. E. Nozell, J. NeuroOncol., 2011, 102, 367-381.

28 K. Miura, H. Karasawa and I. Sasaki, Expert Opin. Ther. Targets, 2009, 13, 1333-1345.

29 K. Shigemasa, O. Katoh, Y. Shiroyama, S. Mihara, K. Mukai, N. Nagai and K. Ohama, Jpn. J. Cancer Res., 2002, 93, 542550.

30 H. Takahashi, M. C. Chen, H. Pham, E. Angst, J. C. King, J. Park, E. Y. Brovman, H. Ishiguro, D. M. Harris, H. A. Reber, O. J. Hines, A. S. Gukovskaya, V. L. Go and G. Eibl, Biochim. Biophys. Acta, 2011, 1813, 1465-1474.

31 K. Simonin, E. Brotin, S. Dufort, S. Dutoit, D. Goux, M. N'diaye, C. Denoyelle, P. Gauduchon and L. Poulain, Mol. Cancer Ther., 2009, 8, 3162-3170.

32 C. Mitchell, A. Yacoub, H. Hossein, A. P. Martin, M. D. Bareford, P. Eulitt, C. Yang, K. P. Nephew and P. Dent, Cancer Biol. Ther., 2010, 10, 903-917.

33 X. Guoan, W. Hanning, C. Kaiyun and L. Hao, Surgery, 2010, 147, 553-561.

34 A. P. Martin, A. Miller, L. Emad, M. Rahmani, T. Walker, C. Mitchell, M. P. Hagan, M. A. Park, A. Yacoub, P. B. Fisher, S. Grant and P. Dent, Mol. Pharmacol., 2008, 74, 807-822.

35 M. Lee, A. Lapham, M. Brimmell, H. Wilkinson and G. Packham, Apoptosis, 2008, 13, 972-982.

36 J. Zhao, X. Ling, S. Cao, X. Liu, S. Wan, T. Jiang and F. Li, Mol. Pharm., 2014, 11, 457-467.

37 P. DiSaia, J. Sinkovics, F. Rutledge and J. Smith, Am. J. Obstet. Gynecol., 1972, 114, 979-989.

38 R. M. Wadkins, P. M. Potter, B. Vladu, J. Marty, G. Mangold, S. Weitman, G. Manikumar, M. C. Wani, M. E. Wall and D. D. Von Hoff, Cancer Res., 1999, 59, 3424-3428. 
39 H. G. Lerchen, J. Baumgarten, K. von. D. Bruch, T. E. Lehmann, M. Sperzel, G. Kempka and H. H. Fiebig, J. Med. Chem., 2001, 44, 4186-4195.

40 W. C. Rose, P. H. Marathe, G. R. Jang, T. M. Monticello, B. N. Balasubramanian, B. Long, C. R. Fairchild, M. E. Wall and M. C. Wani, Cancer Chemother. Pharmacol., 2006, 58, 73-85.

41 G. Gu, H. Lin, Y. Liu, L. Yang, Y. Zheng, B. Wang, C. Tang, H. Qian and W. Huang, Lett. Drug Des. Discovery, 2013, 10, 155-163.

42 S. M. Andersen, M. Heuckendorff and H. H. Jensen, Org. Lett., 2015, 17, 944-947.

43 I. Pendrak, R. Wittrock and W. D. Kingsbury, J. Org. Chem., 1995, 60, 2912-2915.
44 N. Mahindroo, Z. Ahmed, A. Bhagat, K. L. Bedi, R. K. Khajuria, V. K. Kapoor and K. L. Mara, Med. Chem. Res., 2005, 14, 347-368.

45 M. E. Wall, M. C. Wani, A. W. Nicholas, G. Manikumar, C. Tele, L. Moore, A. Truesdale, P. Leitner and J. M. Besterman, J. Med. Chem., 1993, 56, 2689-2700.

46 Y. Bao, L. Zhang and F. Chen, Chin. J. Med. Chem., 2008, 4, 263-267.

47 B. L. Staker, K. Hjerrild, M. D. Feese, C. A. Behnke, A. B. Jr. Burgin and L. Stewart, Proc. Natl. Acad. Sci. U. S. A., 2002, 99, 15387-15392.

48 J. Pan, Y. Qi, X. Zhou, H. Lu and L. Zhang, J. Biol. Chem., 2010, 285, 22966-22975. 